\title{
Possible misconceptions about solid friction
}

\author{
Hasan Şahin Kızılcık®, ${ }^{1, *}$ Müge Aygün $\odot,{ }^{2}$ Esin Şahin $\odot,{ }^{3}$ \\ Nuray Önder-Çelikkanlı®, ${ }^{1}$ Osman Türk® ${ }^{4}$ Tuğba Taşkın $\odot,{ }^{1}$ and Bilal Güneş® ${ }^{1}$ \\ ${ }^{1}$ Physics Education Department, Gazi University, 06560 Ankara, Turkey \\ ${ }^{2}$ Department of Primary Education, Giresun University, 28200 Giresun, Turkey \\ ${ }^{3}$ Science Education Department, Çanakkale Onsekiz Mart University, 17100 Çanakkale, Turkey \\ ${ }^{4}$ Private High School, 06145 Ankara, Turkey
}

(Received 11 March 2021; accepted 22 September 2021; published 12 November 2021)

\begin{abstract}
This study aims to make a thematic classification of possible misconceptions about solid friction by reviewing papers in the literature which include conceptual difficulties about friction; in this way, the study contributes to the literature. The study's scope was limited to the dry friction that occurs with the interaction of two solid objects, as this is included in several curricula. Papers in the literature addressing the conceptual difficulties associated with friction were reviewed. Hence, 42 primary data sources (papers) accessed from various databases were subjected to content analysis. Possible misconceptions about friction were determined by the data collection techniques or tools of the study, the educational levels of the sample, and the countries in which they took place. At the end of the study, a list of possible misconceptions about solid friction were classified and listed under four themes: definition and existence, direction, type and magnitude, and effects of friction. Most of the possible misconceptions are in the type and magnitude theme and the least were in the direction theme. But friction is always opposite to the direction of the motion as a possible misconception was detected in the highest number of papers. Related to this, the possible misconception that friction prevents movement was frequently encountered. It was also found that both the distinction between sliding and rolling friction and kinetic and static friction was often ignored. In addition, some of the possible misconceptions were found to be similar regardless of country, culture, or education system, as in the previous literature. One of the results of the study is that possible misconceptions are not only held by the students but also held by teachers and preservice teachers. In this respect, the results of the study are also considerable in terms of the direction of teachers in in-service training studies.
\end{abstract}

DOI: 10.1103/PhysRevPhysEducRes.17.023107

\section{INTRODUCTION}

Individuals classify the facts according to their similarities and differences by interacting with the environment and developing structures in their minds; these structures can be called concepts [1]. Constructing concepts is what we call conceptualization, and is very important in education. The concepts structured in the individual's mind constitute the cornerstones of the communication of scientific thought [2]. It will be difficult for students who cannot construct concepts well to make scientific knowledge meaningful [3]. According to the constructivist learning theory, any curriculum should have the following three main recognitions [4]: (i) Prior knowledge affects

\footnotetext{
Corresponding author. hskizilcik@gazi.edu.tr

Published by the American Physical Society under the terms of the Creative Commons Attribution 4.0 International license. Further distribution of this work must maintain attribution to the author(s) and the published article's title, journal citation, and DOI.
}

learning. (ii) Students construct knowledge by performing activities. (iii) Students need central concepts as they construct their understanding. While the effect of prior knowledge on learning is directly related to misconceptions, constructing learning around central concepts free from misconceptions is emphasized. These recognitions are intertwined in the context of misconception.

The preknowledge that students bring with them when they come to class has gained importance, along with constructivist learning theory. In explaining the natural phenomena occurring in the environment and making inferences, individuals use the preknowledge obtained through their life and construct their knowledge [5]. Various terms have been used to express the understandings or the preconceptions that students demonstrate, including children's alternative conceptions, nä̈ve beliefs, ideas, conceptual difficulties, intuitive knowledge, phenomenological primitives, prior knowledge, mental models, misconceptions, and so forth [6-10]. Whatever they are called, the main aim is to understand the wrong and flawed conceptions that impede learning or to identify the productive components within these flawed conceptions to use 
them in other contexts [10]. For this reason, to use the term misconception in this study was decided. Since learning is the process of developing existing concepts or creating new ones [11], when these concepts are not compatible with existing scientific paradigms, they can be called misconceptions [12-15]. Misconceptions are obstacles to learning. Many models based on the conceptual change approach, as well as the accommodation and assimilation approach, which are among the models for the remediation of misconceptions, are suggested by various researchers [16]. It may be beneficial to define the misconceptions first to implement practices related to conceptual change.

There are several different definitions of misconception in the literature. We consider misconceptions as cognitive structures that are not scientifically valid. Given this definition, certain conditions need to be fulfilled for a piece of knowledge to be labelled a misconception. First, this knowledge should conflict with scientific knowledge; second, this unscientific knowledge needs to be defended as valid by individuals; third, individuals should be sure that this unscientific knowledge is true [17]. It is thus essential to question whether these three conditions are present when detecting misconceptions. Situations that do not meet all these three conditions are considered scientific errors. In this context, it should be underlined that misconception and scientific error are different concepts. Examining papers on misconceptions, different diagnostic tools, and techniques have been used to measure students' misconceptions: Interviews [18], multiple-choice tests [19], and multiple-tier tests [20-22] are some of them. Since misconceptions are a cognitive process, data collection tools such as multiple-tier tests and interviews that try to measure the mind of the individual come to the fore.

Students may have misconceptions about the topic when they come to the classroom. Since the constructivist approach cares about students' readiness, it is critical for teachers to be able to predict which misconceptions the students may have about the topic. That is why they should know the misconceptions in the literature, and they can make teaching more efficient. However, studies that thematically classify misconceptions in many topics and review the current literature are quite limited.

\section{A. Physics education and concept of friction}

Learners use many mental models to understand physical phenomena, and these models may involve multiple representations depending on the context in which they occur [23]. Many students have difficulties in understanding various science subjects and may frequently have misconceptions. Several studies have found that physics is a subject in which students have learning difficulties [24-26]. There are thus many papers on students' misconceptions, and how to detect these misconceptions and overcome them. Indeed, it was determined in various studies examining the papers in science education that misconceptions and difficulties in learning are among the most common topics in this area [27-32].

In physics education, as in the education of other fields, the conceptualization process plays a central role. Conceptualization includes what the concepts mean, as well as inter-conceptual relationships that allow scientific interpretation of physical phenomena. This process facilitates the learning of scientific theories. According to physics teachers who focus on conceptual teaching, learning mechanics is a specific problematic topic [33]. Many studies have determined that students, teachers, and preservice teachers have a wide range of misconceptions about force and motion, which are among the main topics within mechanics [34-40]. Some of these misconceptions are related to the concept of friction. This concept appears in the literature as friction, friction force, frictional force, or force of friction. In the current study, the preferred term is friction. Friction refers to the electrostatically induced force affecting objects in motion or due to two objects in contact being forced into motion. Friction as used throughout this study means the friction between two dry and solid surfaces.

The concept of friction has a central role in mechanics in the context of friction in rigid bodies. It must be acquired to understand both the conservation of energy and Newton's laws. Friction is one of the concepts that students have difficulty understanding, as have professional scientists [41]. Friction in solids has been dealt with by many scientists over time and various theories have been put forward, in both macro- and microdimensions. The development of scientific knowledge on friction has been summarized by Corpuz [42] and Popova and Popov [43]. The main events are as follows.

It is thought that the first systematic research on friction belonged to da Vinci (1452-1519), but the first explanation of sliding friction between inelastic solids was made by Amontons (1663-1705). According to Amontons friction is proportional to the normal force and independent of a sliding solid objects' surface area. Coulomb (1736-1806) argued that kinetic friction is generally independent of the relative velocity of the contacting surfaces. On the other hand, he also specifically stated that friction depends on relative velocity when the weight/surface area (W/A) ratio of the object is too small or too large. Coulomb also noted that friction changes slightly because of the surface area on some pairs of surfaces (e.g., oiled wooden surfaces). Another of his observations was that the static friction coefficient is greater than the kinetic friction coefficient in materials other than metals.

\section{B. Friction in curricula}

In studying friction, the aim is that students learn about the effects of friction in their daily experiences. The curricula of various countries show us this. For example, the "importance of friction in everyday experience, e.g., 
walking, use of lubricants, etc." is emphasized in the Irish physics curriculum [44], while one of the outcomes in the physics curriculum for Ontario, Canada is "analyzes the advantages and disadvantages of friction within mechanical systems in real-world situations, as well as methods used to increase or reduce friction in these systems" [45]. A related outcome in Turkey's physics curriculum is "gives examples of the advantages and disadvantages of friction in daily life" [46].

The curricular emphasis on friction in daily experiences appears in various contexts and regarding very basic activities such as walking, running, or holding objects. Although we feel the effects of friction in every aspect of our lives and it is impossible to create an environment in which there is no friction in the Universe, modeling the friction in a cause-and-effect relationship can be difficult. This is because "friction at the microscopic scale is mediated by electrostatic van der Waals interactions, while at the macroscopic scale it is merely described as a contact force between two surfaces in relative motion" [23]. It should not be forgotten that microscopic friction is a specific field that continues to be explored by experts [47]. Curricula usually expect students to identify the type and magnitude of friction to relate it to everyday life rather than interpreting what friction is. For example, a secondary school physics curriculum has an outcome of "Analyzes the variables that contribute to frictional force" with an explanation of "Compares static and kinetic friction forces" [46].

Friction, which manifests different characteristics in solids and fluids, primarily appears in curricula regarding solids. Nevertheless, since the early 19th century, despite the studies of Amontons and Coulomb and their different findings [e.g., [48-50]], friction has been explained in many textbooks in the following restricted ways:

- Friction is proportional to the normal force.

- Friction is independent of the surface area of solid objects.

- Friction is independent of the relative velocity of the contacting surfaces.

- The coefficient of static friction is slightly greater than the coefficient of kinetic friction.

\section{Purpose and importance}

This study reviewed papers in the literature that included possible misconceptions (PMCs) about friction and classified them thematically. Students often have difficulties understanding solid friction, one of the topics within mechanics [41]. It is thought that the classification made within the scope of the current study will provide a rich resource that will allow researchers and educators to see all the PMCs about the friction so far identified. Given the importance of learning, which is free from misconceptions, it is considerable to know what the common misconceptions about friction are or might be. Friction is listed as a concept about which there are one or two misconceptions in different topics in the literature, especially about Newton's laws of motion [51-53]. However, a previous study in which misconceptions about friction were classified in detail could not be found. Consequently, it is important to review the studies in the literature on friction and to collect the highlighted PMCs in a single study.

Teachers design educational programs and lessons and are also expected to guide their students' learning. They are thus expected to know about the common misconceptions, the sources of these misconceptions, and which misconceptions their students may have [54,55], as well as to be able to deal with them [54]. The thematic classification that emerges in this study provides an ongoing point of reference for teachers and preservice teachers when discussing friction-related issues in their lessons. It may also function as a reference for those students who take responsibility for their own learning. The contextual statements and terms that were used in the papers examined were thus also included in the current study. Anyone examining the thematic PMC lists is thus also provided with information about the contexts in which PMCs may arise.

It appears that there are problems with the definition of friction in popular science books, university, high school, and middle-school textbooks, and even in dictionaries [2]. It is hoped that the thematic PMC list presented here may also be a reference for others. In addition, the study may be beneficial for researchers and educators in terms of identifying the trends and gaps in the literature and determining their future research paths, the measurement tools they will develop, and the lesson plans they will prepare. Within the scope of this study, answers were sought to the following questions about academic papers on friction:

- Which PMCs have been identified in the papers?

- Under which themes can the PMCs identified in the papers be classified?

\section{METHOD}

This study, which had a qualitative research design, is a review study. Review studies are effective methods of writing papers that allows for a systematic synthesis of previous papers [56,57]. These studies can have more power than single studies by combining the findings and perspectives of different papers [58].

\section{A. Data collection}

To obtain the papers to be evaluated in this study, each author of this study independently conducted a literature search. Online databases (Web of Science [WoS], Education Resources Information Center [ERIC], and Google Scholar [G.Scholar]) containing publications in the field of social sciences and educational sciences were searched for papers about misconceptions. Friction, 
frictional force, misconception, etc., were used as key words, in both Turkish and English. In addition to this, attempts were made to find other papers related to friction with the help of key words such as mechanics, Newton's laws, force, and motion.

In searching the literature, it was decided to include papers about misconceptions, even if they did not use the specific expression misconception. For example, expressions like students' ideas, common ideas, or common difficulties were considered to indicate PMCs, and searches were also made using these terms. Although these papers did not specifically discuss misconceptions, all these terms were regarded as potentially discussing misconceptions and were investigated within the scope of this study. The following inclusion criteria were applied to each paper:

- The paper must have been conducted in the field of education.

- The paper must have been written in Turkish or English.

- It must have included a discussion of PMCs about friction.

- It must have been available in full text.

- It must have been a primary source: documentary analysis of the papers, textbooks that listed misconceptions, and web pages presenting some papers' results were not included. While examining the papers within the scope of these criteria, we preferred to read the whole paper, not just the findings or results and conclusions. Thus, it was possible to see whether the PMC was given based on the literature or was it determined during the research process. PMC was considered if it was derived from the research process.

\section{Bibliometrics of papers}

The study included 42 papers (see Appendix). For the readers of this review, the bibliometric information of the papers in which PMCs were identified may be important; locale of the study, language, database, data collection method or tool, sample level, and sample size of the papers are summarized in Table I. The process allowed the formation of Table I as follows: While determining the countries where the research was conducted, the information from which country the data of the study were collected by using information such as the country, city, or school. In only one research there is no information on the country where the research was conducted. This research was coded as "..." for location. While examining the databases, primarily WoS was searched; then ERIC was searched, then G. Scholar. Thus, for example, a paper that can be found in both WoS and ERIC is seen as found in WoS. While determining how the data of the papers were collected and the sample levels, the information presented in the methods section of the papers was taken directly. If this information was not presented in the paper, it is interpreted to other sections of the paper such as results or appendices by the researchers. Interpreted papers are indicated with a $(* *)$ in Table I.

As seen in Table I, the locales varied: 12 different countries and one unknown country. Turkey was the country from which most papers originated with 15 papers. This was followed by Indonesia with six papers and the United States with five papers. Three or fewer papers were identified in other countries. One of the study's limitations was that we only had fluent knowledge of Turkish and English, and the fact that we only reviewed papers in these languages may have led to this result. However, only nine of the 42 papers were in Turkish. The remaining 33 were in English. Nevertheless, the number of papers in Turkish may be seen as the reason for the high number of research conducted in Turkey. If only papers in English had been considered, the order of frequency would have been as follows: Indonesia $(n=6)$, Turkey $(n=6)$, and the United States $(n=5)$, with the other countries all featuring in fewer than five papers. On the other hand, the paper counts in the United States and the United Kingdom, where English is common, are not very high.

The data collection techniques or tools of the papers were varied. The most common data collection techniques or tools were interviews $(n=16)$, multiple-choice tests $(n=12)$, multiple-tier tests $(n=11$ : eight two-tier tests, three three-tier tests, and one four-tier test), and open-ended tests $(n=9)$ in order of frequency. Many of the papers included undergraduate students. Elementary school students, graduate students, and teachers were included in a small number of them.

\section{B. Data analysis}

The papers included in the review were used to create a thematic PMC list by content analysis. Content analysis organizes and interprets similar data by collecting them under specific themes [59]. The data synthesis process took three months. During this process, the following procedures were carried out.

For coding of the data, we prepared a paper review table to gather the data systematically. This table included the following: the PMC, the data collection techniques or tools, the educational levels of the sample, and the locale where the research was conducted. The papers obtained were shared among ourselves, and each one of us independently filled out an analysis table. The table used and an example of coding are shown in Table II.

To increase the reliability of the coding, the terms and statements used in the papers were placed in the table as direct quotes placed in the quotations of PMCs column. It has been seen that in some papers PMC is expressed independently of the context and in some of them in a context. It has been represented in the tables in both cases, by staying true to the essence of the paper.

We reached 42 codes from 42 papers, purely by chance by merging the paper review tables. Then we classified 
TABLE I. Bibliometrics of the papers.

\begin{tabular}{|c|c|c|c|c|c|c|}
\hline No. & Locale & Lang. & Database & Data collection & Sample level & Sample size \\
\hline 1 & NG & EN & ERIC & Interview, Mixed-structure test ${ }^{* *}$ & High school science teachers & 251 \\
\hline 2 & HR & EN & WoS & Two-tier test & First year undergraduate students & 52 \\
\hline 3 & IT & EN & WoS & Open-ended test & Student teachers & 58 \\
\hline 4 & TR & EN & G.Scholar & Two-tier test & First year undergraduate students & 36 \\
\hline 5 & $\mathrm{KZ}$ & EN & WoS & Drawing test, Interview & 7 th grade students & 62 \\
\hline 6 & ID & EN & WoS & Three-tier test & Undergraduate students & 28 \\
\hline 7 & PT & EN & ERIC & Open-ended test ${ }^{* *}$ & $\begin{array}{l}\text { Physics teachers; senior students } \\
\text { of physics education courses }\end{array}$ & 15 \\
\hline 8 & $\cdots$ & EN & G.Scholar & Two-tier test & First year undergraduate students & 42 \\
\hline 9 & US & EN & G.Scholar & Interview & Introductory college physics students & 20 \\
\hline 10 & US & EN & WoS & Interview & Introductory college physics students & 11 \\
\hline 11 & US & EN & WoS & Teaching interview & Introductory college physics students & 11 \\
\hline 12 & IT & EN & WoS & Multiple-choice test & Graduate students & 20 \\
\hline 13 & GB & EN & ERIC & Mixed-structure test & First year undergraduate students & 108 \\
\hline 14 & TR & TR & G.Scholar & Multiple-choice test & First year undergraduate students & 268 \\
\hline 15 & TR & $\mathrm{EN}$ & G.Scholar & Multiple-choice test & 7 th and 8 th grade students & 287 \\
\hline 16 & TR & TR & G.Scholar & Multiple-choice test & 7 th grade students & 29 \\
\hline 17 & ID & EN & G.Scholar & $\begin{array}{l}\text { Interview, concept } \\
\text { understanding test }\end{array}$ & First year undergraduate students & 25 \\
\hline 18 & ID & EN & ERIC & Two-tier test, Four-tier test & Senior high school & 30 \\
\hline 19 & TR & EN & G.Scholar & Drawing test & First year undergraduate students & 54 \\
\hline 20 & TR & EN & ERIC & Interview & Sophomore university students & 1 \\
\hline 21 & GB & EN & WoS & Multiple-choice test & Primary school teachers & 159 \\
\hline 22 & TR & EN & WoS & Open-ended test & 12th grade & 215 \\
\hline 23 & TR & TR & G.Scholar & Open-ended test & $\begin{array}{l}\text { 10th grade students; first year and } \\
\text { last year undergraduate students }\end{array}$ & $60 ; 120$ \\
\hline 24 & TR & TR & G.Scholar & Open-ended question & 4 th, 5 th, 6 th, 7 th, 8 th grade students & 125 \\
\hline 25 & TR & TR & G.Scholar & Three-tier test & 7 th grade students & 280 \\
\hline 26 & $\mathrm{TH}$ & EN & G.Scholar & Multiple-choice test & 9th grade students & 93 \\
\hline 27 & $\mathrm{TH}$ & EN & WoS & Interview, Open-ended test & First year undergraduate students & 241 \\
\hline 28 & $\mathrm{TH}$ & EN & ERIC & Teaching interview & High-school students & Unknown \\
\hline 29 & TR & TR & G.Scholar & Interview, Open-ended test & 6 th grade students & 20 \\
\hline 30 & ID & EN & WoS & $\begin{array}{l}\text { Interview, Multiple-choice } \\
\text { questions with reasons }\end{array}$ & 4th grade students & 24 \\
\hline 31 & US & EN & WoS & $\begin{array}{l}\text { Interview, Multiple-choice } \\
\text { paired problems }\end{array}$ & First year undergraduate students & 387 \\
\hline 32 & US & EN & WoS & Multiple-choice test & Undergraduate students & 1331 \\
\hline 33 & $\mathrm{AU}$ & EN & WoS & $\begin{array}{l}\text { Group conversational interactions, } \\
\text { Two-tier test, interview, quiz }\end{array}$ & 10th grade students & 12 \\
\hline 34 & TR & TR & G.Scholar & Two-tier open-ended test, drawing & 10th grade students & 108 \\
\hline 35 & TR & EN & WoS & Interview, Open-ended test & Undergraduate students & 116 \\
\hline 36 & IL & EN & ERIC & Drawing, multiple-choice test & Undergraduate students & 68 \\
\hline 37 & IL & EN & ERIC & Drawing, multiple-choice questions & Undergraduate students & 180 \\
\hline 38 & TR & TR & WoS & Two-tier open-ended test & 10th grade students & 186 \\
\hline 39 & $\mathrm{HR}$ & EN & WoS & Multiple-choice \& open-ended test & Undergraduate students & 184 \\
\hline 40 & ID & EN & G.Scholar & Drawing test, Interview & First year undergraduate students & 33 \\
\hline 41 & ID & EN & WoS & Interview, Two-tier test & Sophomore university students & 24 \\
\hline 42 & TR & TR & G.Scholar & Three-tier test & First year undergraduate students & 149 \\
\hline
\end{tabular}

similar PMCs thematically, inductively. The preliminary thematic classification was evaluated separately by two groups of three people. One of us was excluded from the discussions to maintain the objectivity of the comments and discussion. The two groups came together and discussed the preliminary thematic classification until full consensus was reached. In any disagreement, the papers which had identified the PMC in question were reviewed repeatedly. 
TABLE II. The table used to collect data during the research process (columns related to bibliometrics of papers excluded).

\begin{tabular}{lcc}
\hline \hline Paper No. & Reference & Quotations of PMCs \\
\hline 28 & Prasitpong \& & "The frictional force direction \\
Chitaree (2010) & $\begin{array}{l}\text { is always opposite with the } \\
\text { motion of the object." }\end{array}$ \\
\hline \hline
\end{tabular}

Thus, all the themes were formed inductively. In the thematic list tables, each theme was presented with some sample quotations which were taken directly from related papers. In presenting the findings, at most two sample quotations were given for each PMC. Since some PMCs were detected in only one paper, if PMCs were detected in more than one paper the following criteria were considered. (i) If a PMC was detected in only one paper, the sample quotation was given. (ii) If a PMC was detected in two or more papers, the best two sample quotations that showed the least similarity to each other in terms of content were selected. This was done to try to ensure that all the elements that made up a theme were represented. Furthermore, in presenting the paper(s) (see Appendix) from which the sample quotation(s) were selected, the numbers were given in the parentheses after the sample quotation(s) in the tables.

Expert opinions were sought to determine the content validity of the thematic classification. The classification of authors was reviewed by seven experts with Ph.D.s in physics education. Experts who had conducted papers about misconceptions from three different universities in Turkey contributed to the study. The teaching and research experiences of these experts varies between 15 and 28 years. The age range of the experts is 36 to 50. Two are female and five are male. Their titles are as follows: One is a doctor, two are associated professor doctors, and four are full professor doctors. The degrees of agreement among the experts were calculated separately for each PMC by the kappa coefficient. The kappa coefficient has been proposed as a measure of content validity and is a consensus index of inter-rater agreement that adjusts for chance agreement [60]. Wynd, Schmidt, and Schaefer argued that the kappa coefficient provides information about the degree of agreement beyond chance [61]. Like most consensus indexes of interrater agreement, kappa provides consensus about the relevance or nonrelevance of an item [60]. The kappa coefficient adjusts better than other fit indices [61]. The kappa coefficients of the PMCs varied between 0.66 and 1.00. The average kappa coefficients of each theme separately were found to be $0.95,0.91,0.90$, and 0.82 , respectively. The general average kappa coefficient was found to be 0.89 . A kappa value above 0.60 is interpreted as substantial [62,63], and a value of 0.75 or above is interpreted as excellent [62-64]. After all, the excluded author reviewed the data analysis for consistency by reading all the tables, explanations, and discussions.
The final classification consisted of a total of 42 codes and four themes. These themes were definition and existence of friction, direction of friction, type and magnitude of friction, and effects of friction. Let us think of these themes as a desk (Fig. 1). The desk board is in the center, the supporting legs are on the sides, and the load is on the desk board. Theme 1: The definition and existence of friction, which is perhaps the basis of all PMCs, is the desk board as the carrier board of the desk. Because if the definition of a concept is unknown, it will be difficult to interpret that concept. At the same time, to know the definition of a concept, it is necessary to know about the conditions in which it occurs. Therefore, the two features were themed together. As well, its various properties should be known to make inferences and comments about its effects. So, our desk can be thought of as a three-legged desk with type, magnitude, and direction since all the PMCs we have dealt with related to direction were unbound to the type, but some of the PMCs related to magnitude were bound to the type. Thus, we assume that the desk we created has two legs. Thus, two different themes emerged for the supporting legs, namely, Theme 2: The Direction of Friction, and Theme 3: The Type and Magnitude of Friction. When the PMCs in these two themes come together with the PMCs in theme 1, it is apparent that they can also be the source of the PMCs in Theme 4: The Effects of Friction. Theme 4 is the load that the desk should carry. Considering our first goal in teaching friction is to raise individuals who can make inferences and comment on its effects.

According to Fig. 1, PMCs that are related to what friction is (e.g., "Friction exerted on an object by the supporting surface is its pulling force, friction is not a force") and the conditions on which the presence or absence of friction depends (e.g., "Whenever there is motion, there must be friction, no friction is acting on an object that is at rest if an external force is exerted on it and it stays at rest") were included in theme 1. PMCs related to the direction of friction (e.g., "Friction is always opposite to the direction of the motion.") were included in theme 2. In this theme, expressions related to the direction of motion, the direction of force or acceleration, and the axis of friction have come together. PMCs related to the type and magnitude of friction were included in theme 3. Some of the PMCs in this theme only discussed the type of friction (e.g., "when the object moves, kinetic friction always acts between the contact areas"), others only the magnitude (e.g., "friction depends on the magnitude of the contacting surfaces"), still others the type and magnitude together (e.g., "static friction is at a minimum when the object starts to move"). Finally, PMCs are related to various effects of friction, such as energy transformations (e.g., "friction always converts mechanical energy into heat") and causing or preventing motion (e.g., "Friction always hinders motion") were included in theme 4. 


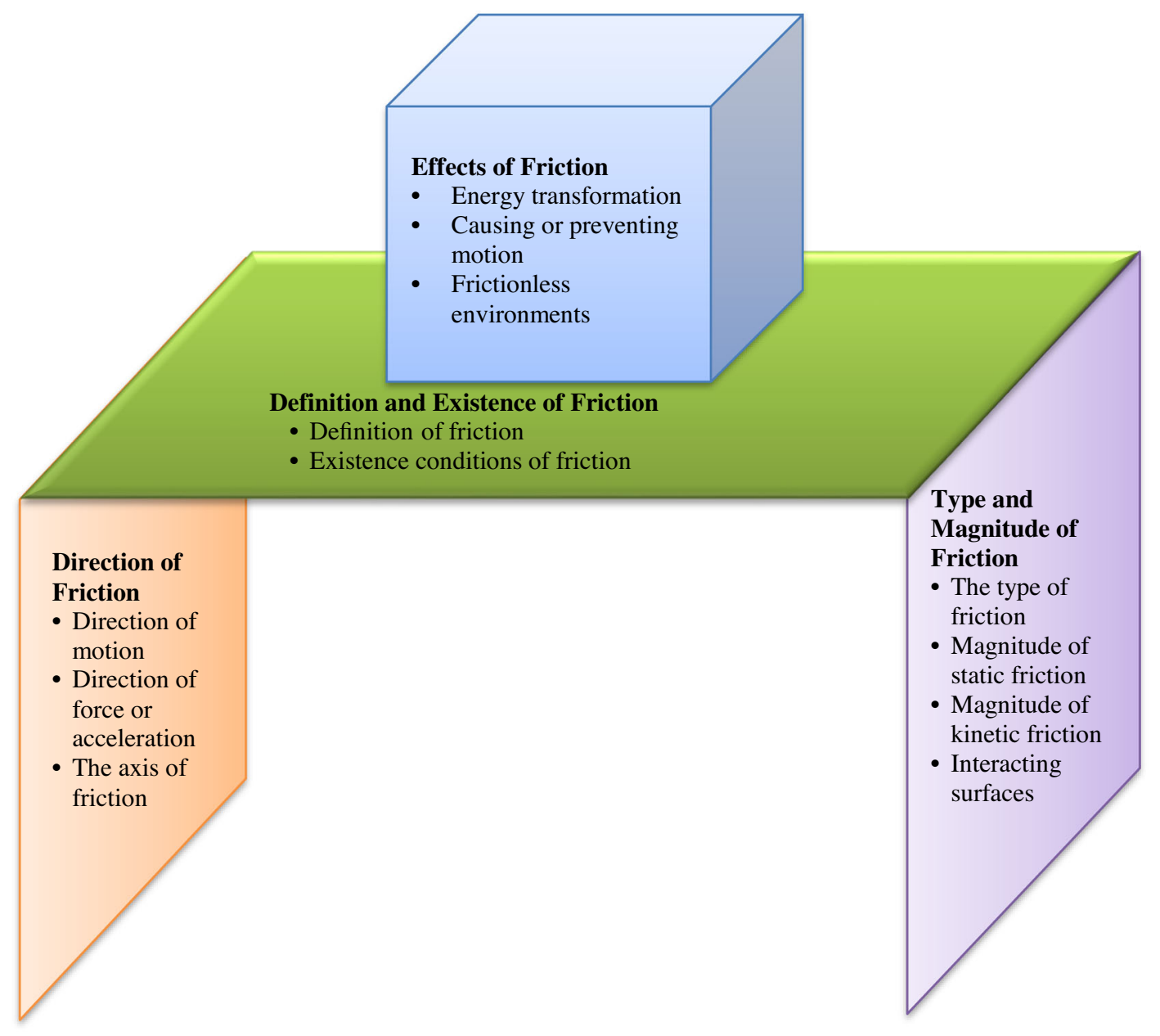

FIG. 1. Desk analogy of PMC themes.

\section{RESULTS AND DISCUSSION}

The results and discussion are presented in two main sections. The first of these is themes and PMCs. The second is the relationship between bibliometrics of papers and PMCs with themes.

\section{A. Themes and PMCs}

We see two different misconceptions classifications about friction in the literature. Akbulut classified misconceptions about friction under four headings: its interaction with substance, its effect on velocity, its effect on tools, and its effect on movement [65]. Develi and Namdar, on the other hand, studied three themes: the definition of the concept of friction force, situations where friction force is effective, and the direction of friction force [2]. In this study, 42 PMCs related to friction were detected. They are inductively placed into four different themes which are the direction of friction, the definition and existence of friction, type and magnitude of friction, and the effects of friction. The main difference with the older ones is that here the type and magnitude of friction was also considered as a theme.
The aim of this new classification was not to squeeze the available data into an existing thematic structure but rather to create a thematic structure suitable for the data.

In the 1990s, many students had common misconceptions about friction, and these were mostly about the direction of the force [66]. But in this study about $31 \%$ of the PMCs were in the type and magnitude of friction theme, $26 \%$ were in the definition and existence of friction theme, $26 \%$ were in the effects of friction theme, and $17 \%$ of them were in the direction of friction theme.

\section{Theme 1: The definition and existence of friction}

11 different PMCs were found on the definition of friction and its conditions of existence, from 18 papers. Four of these (A1, A2, A3, and A4) were related to the definition of friction, while seven of them (A5, A6, A7, A8, A9, A10, and A11) were related to its conditions of existence (Table III).

The PMC detected in five different papers discussing the effects of friction, was A7. One of the PMCs detected in four different papers was $\mathrm{A} 1$, which was related to the definition of friction, while the other was A6, which was 
TABLE III. PMCs related to the definition and existence of friction.

\begin{tabular}{|c|c|c|c|}
\hline No. & PMC & Sample quotation & Paper No. \\
\hline A1 & Friction is not a force. & $\begin{array}{l}\ldots \text { the status of friction as a force [is uncertain] } \ldots \\
\text { (21) Friction is not a force... (25) }\end{array}$ & $21,25,36,42$ \\
\hline A2 & Normal force and friction are the same. & Normal force is equal to frictional force. $(24,38)$ & 24,38 \\
\hline A3 & $\begin{array}{l}\text { Friction exerted on an object by the supporting } \\
\text { surface is its pulling force. }\end{array}$ & $\begin{array}{l}\ldots \text { the frictional force exerted on a man ... by the } \\
\text { supporting surface is considered to be his pulling } \\
\text { force. ( } 2 \text { ) }\end{array}$ & 2 \\
\hline A4 & $\begin{array}{l}\text { Friction exerted on an object moving in the inclined } \\
\text { plane is the component of gravity. }\end{array}$ & $\begin{array}{l}\text {...frictional force [in the inclined plane] as a } \\
\text { component of gravitational force... (2) }\end{array}$ & 2 \\
\hline A5 & Whenever there is motion, there must be friction. & $\begin{array}{l}\text { Whenever there is motion, there must be a frictional } \\
\text { force [even if the object also rotates]. (7) }\end{array}$ & 7 \\
\hline A6 & $\begin{array}{l}\text { Friction acts on objects that do not move even if an } \\
\text { external force is not applied. }\end{array}$ & $\begin{array}{l}\text { The friction force affects the stopping objects. ( } 15 \text {, } \\
16,23) \text { The force acting on the wooden block } \\
\text { standing on a horizontal table is only friction [or] } \\
\ldots \text { the weight of the block, the reaction of the } \\
\text { table, and friction. (42) }\end{array}$ & $15,16,23,42$ \\
\hline A7 & $\begin{array}{l}\text { No friction is acting on an object that is at rest even if } \\
\text { an external force was applied to it and it stays at } \\
\text { rest. }\end{array}$ & $\begin{array}{l}\text { When an object remains at rest though there is an } \\
\text { external force acting on it, the frictional force } \\
\text { acting on the object is always equal to zero. ( } 8 \text { ) } \\
\text { No friction is acting on an object that is at rest even if } \\
\text { an external force was exerted to it and it stays at } \\
\text { rest. (26) }\end{array}$ & $1,8,13,26,37$ \\
\hline A8 & $\begin{array}{l}\text { Friction occurs only on one of the two objects in } \\
\text { contact. }\end{array}$ & $\begin{array}{l}\text {...there is only a single friction force ... forget the } \\
\text { force applied to a body below another body. (3) }\end{array}$ & 3 \\
\hline A9 & Friction only exists between two solid surfaces. & Friction only exists between two solid surfaces. (25) & 25 \\
\hline A10 & $\begin{array}{l}\text { When the object moves with a constant velocity, no } \\
\text { friction acts. }\end{array}$ & $\begin{array}{l}\text { When the object is pulled with a constant velocity, } \\
\text { there is no force, no frictional force as well. ( } 27 \text { ) }\end{array}$ & 27 \\
\hline A11 & $\begin{array}{l}\text { Friction does not act on the objects with increasing } \\
\text { speed. }\end{array}$ & $\begin{array}{l}\text { Among the staggeringly high proportion who did not } \\
\text { believe friction was present the most common } \\
\text { reason given to support this view was that the } \\
\text { person was speeding up on the slide. (1) }\end{array}$ & 1 \\
\hline
\end{tabular}

related to the effects of friction. All the remaining PMCs in this theme were determined by one paper each.

Various PMCs were encountered about the definition of friction, such as it not being a force or it being a type of force. In addition to the statement "Friction is not a force" (25) encountered in seventh-grade students in A1, some teachers' stated that "the status of friction as a force [is uncertain]" (21). These PMCs related to friction being a force may have affected PMCs related to the PMCs that friction exerted on an object by the supporting surface is its pulling force (2) in A3 and friction exerted on an object moving in the inclined plane is a component of gravity (2) in A4. Driver, Guesne, and Tiberghien stated that "If friction is not identified as a force, students could develop an intuitive image that constant movement requires a constant force" [2].

"Whenever there is motion, there must be a frictional force (even if the object also rotates)." (7), which was encountered in A5 in physics teachers and senior students of physics education courses, shows that static friction is ignored in friction-related situations. In fact, friction is defined over motion and slide in textbooks [2]. In this case, is kinetic friction understood as being the only kind of friction? Could the underlying reason for the PMC be that friction is in the opposite direction to motion (theme 2)? On the other hand, the statements, "The friction force affects the stopping objects" $(15,16,23)$ in A6, and "No friction acts on an object that is at rest even if an external force is exerted on it and it stays at rest" (26) in A7 show that there are misconceptions about static friction.

In the A8, the statement is encountered that "there is only a single friction force... forget the force applied to a body below another body" (3), where friction is not thought to act simultaneously on two surfaces in contact with each other. However, in A9, although the statement "friction only exists between two solid surfaces" (25) referred to the situation as it relates to nonsolid surfaces, since this is outside the limits of this study, the PMCs seen in the literature were not included in the findings.

\section{Theme 2: The direction of friction}

Seven different PMCs were encountered regarding the direction of friction, from 15 papers. Three of them (B1, $\mathrm{B} 2$, and B3) relate to the direction of motion, three (B4, B5, and B6) to the direction of force or acceleration, and one (B7) to the axis of friction (Table IV). 
TABLE IV. PMCs related to the direction of friction.

\begin{tabular}{|c|c|c|c|}
\hline No. & PMC & Sample quotation & Paper No. \\
\hline B1 & $\begin{array}{l}\text { Friction is always opposite to the } \\
\text { direction of the motion. }\end{array}$ & $\begin{array}{l}\text { When a person is pedaling a bicycle, the } \\
\text { frictional force acting on the rear wheel of } \\
\text { the bicycle is along the backward } \\
\text { direction. (8) The frictional force direction } \\
\text { is always opposite with the motion of the } \\
\text { object. (27) }\end{array}$ & $3,5,6,7,8,22,27,28,40$ \\
\hline B2 & $\begin{array}{l}\text { The direction of friction acting on the } \\
\text { moving object is in the same direction } \\
\text { as the motion. }\end{array}$ & $\begin{array}{l}\ldots \text { there is frictional force } \ldots \text { in the }+\mathrm{x} \\
\text { direction [direction of the motion on the } \\
\text { inclined plane]. (34) } \\
\text {... others drew the friction in the direction of } \\
\text { the movement. (36) }\end{array}$ & $34,36,37$ \\
\hline B3 & $\begin{array}{l}\text { Friction is always opposite to the } \\
\text { direction of rotational motion. }\end{array}$ & $\begin{array}{l}\text { Friction force direction on the object is } \\
\text { opposite to the rotation motion (6). } \\
\text {.. if bicycle is moved to the front/left, the } \\
\text { wheel will rotate counterclockwise. The } \\
\text { direction of the rotation of the wheel } \\
\text { causes the direction of the friction force } \\
\text { towards the front/left. (40) }\end{array}$ & $6,7,40$ \\
\hline B4 & $\begin{array}{l}\text { Friction is always opposite to the } \\
\text { direction of the external force. }\end{array}$ & $\begin{array}{l}\text { The direction of the force to the right, so the } \\
\text { direction of the frictional forces to the } \\
\text { left... (17) } \\
\text { Friction force is always opposite to the force } \\
\text { applied to the object. (19) }\end{array}$ & $3,17,19,27$ \\
\hline B5 & $\begin{array}{l}\text { The friction acting on the moving object } \\
\text { is in the same direction as the applied } \\
\text { force. }\end{array}$ & $\begin{array}{l}\text { The frictional force [acting on the moving } \\
\text { object] is in the same direction as the } \\
\text { applied force. (29) }\end{array}$ & 29 \\
\hline B6 & $\begin{array}{l}\text { Friction is always opposite to the } \\
\text { direction of the acceleration. }\end{array}$ & $\begin{array}{l}\text { When the rider turns his bicycle at the corner } \\
\text { of the road, the frictional force acting on } \\
\text { the front wheel is in the outward direction. } \\
\text { (8) } \\
\text { The direction of the frictional force is } \\
\text { opposite with that of acceleration. (27) }\end{array}$ & 8,27 \\
\hline B7 & Friction is always horizontal. & $\begin{array}{l}\text {...the friction force is [not] vertical or } \\
\text { oblique. (3) }\end{array}$ & 3 \\
\hline
\end{tabular}

Examining the PMCs in Table IV in detail, the topics of rolling and translational movements stand out clearly in this theme. Additional explanations are thus given below to understand the contents of these PMCs:

B1 was detected in the highest number of papers (nine papers). This PMC was identified separately in some of the papers for translational motion, in some papers for objects that make a rolling motion, and, in other papers, for objects that make rolling and translational motions. Regardless of which type of movement was determined, in all these papers, the expression opposite to the direction of the motion in PMC expressed the opposite of the translational motion.

B2 was only encountered in three papers in examples of objects that have translational motion. B3 was seen in three papers that discussed rolling objects. This PMC is opposed to B1 on the rolling motion. That is, in this PMC, it is indirectly stated that the direction of friction is the same as the direction of the translational motion. Rimoldini and
Singh also revealed that several students did not know the meaning of rolling without slipping [67]. Some believed that the objects would roll better if there were no friction; others believed that an extremely large coefficient of static friction does not allow for any movement, even if the inclined plane is almost vertical. B3 may arise when the effect and role of friction in the rotation of the rotating object cannot be understood.

B4 was detected regarding translational motion in one of the papers and regarding rolling motion in two of the papers; in one paper it was not specified what kind of motion is referred to. B5, which was found only in one paper, was based on a general question asked of the students (without specifying either translation or rolling movement). B6, which was detected in two papers, appeared in examples related to rolling objects in both papers. Translational acceleration was mentioned in one, while the centripetal acceleration was mentioned in the other. 
B7 was determined in discussion of an object to which horizontal force is applied in the vertical plane. Regarding B7, the statement that embodies this is that "the friction force is [not] vertical or oblique" (3). This may be a result of overgeneralization by individuals due to the horizontal direction often being used as a starting point for friction in textbooks. Similarly, Rimoldini and Singh showed that many students believed that the drag force was completely vertical when helicopter wings are inclined at an angle with respect to the horizontal [67].

All the papers used in determining B3 (three papers) and B6 (two papers) were also used in determining B1. Thus, these three PMCs may have a relationship. All three are based on using opposition to determine the direction of friction. They think that acceleration and the direction of motion are parallel. Also, movement at the point of contact is relative motion. Therefore, these PMCs may have occurred when determining the direction of friction because the relative motion of the contacting surfaces was incorrectly correlated with the motion and acceleration of the object.

The contextual expressions about friction being opposite to motion or acceleration were mostly related to rotational motion. On the other hand, the PMCs regarding the direction of the motion and the force or acceleration direction were similar. These PMCs generally involve the thought that friction always hinders motion and has negative effects. Some of the papers discussing these PMCs have also covered the relevant PMCs within the theme effects of friction. From another point of view, the statement that the direction of friction is opposite to the net force that enforces the contact surface to slide may also be misinterpreted.

\section{Theme 3: The type and magnitude of friction}

13 different PMCs about the type and magnitude of friction were encountered, from 21 papers. Three of them (C1, C2, and C3) were related to determining the type of friction, four of them $(\mathrm{C} 4, \mathrm{C} 5, \mathrm{C} 6$, and $\mathrm{C} 7)$ were related to the magnitude of static friction, one of them (C8) was related to the magnitude of the kinetic friction, and five of them $(\mathrm{C} 9, \mathrm{C} 10, \mathrm{C} 11, \mathrm{C} 12$, and $\mathrm{C} 13)$ were related to interacting surfaces (Table V).

The PMC detected in six different papers, which was associated with interacting surfaces, was C11. The PMC detected in four different papers, which was associated with the value of static friction, was C4. In addition, C5 was determined in two papers, $\mathrm{C} 10$ in three papers. All the remaining PMCs in this theme were determined by one paper each. It can thus be said that $\mathrm{C} 4$ and $\mathrm{C} 11$ were more common than the other PMCs in this theme.

The first three PMCs related to the type and the magnitude of friction are about ignoring the effect of static friction on rotational or rolling motion. The statement "When the object moves; the kinetic friction always acts between the contact areas (which are not sliding against each other)" (27) related to $\mathrm{C} 1$, and the statement that "Static friction is worth a minimum when the object will start to move." (18), which is related to $\mathrm{C} 2$, demonstrate this. The statement that "Kinetic friction and rolling friction are equivalent designations for friction: the first one is used for sliding objects, while the second one is used for rolling objects." (7), which is related to C3, can be added to the previous two.

On the other hand, there are various PMCs regarding the magnitude of static friction. These are seen in the statements that "The static friction is always at the maximum value" (31) in $\mathrm{C} 4$, that the "... magnitude of friction that occurs on an object [at rest] is greater than the magnitude of force deployed by someone who gives the force." (30) in C5, and with the statement that "... static friction... [does not] varies in magnitude... depending on the external force." (3) in C6. On the other hand, one PMC is encountered regarding the transition from static friction to kinetic friction. The statement in $\mathrm{C} 8$ is as follows: "If there is a force of $10 \mathrm{~N}$ acting on a rest object on a plane and the object moving with acceleration, this means a friction of more than $10 \mathrm{~N}$ is acting on it" (26).

Two different situations are encountered in C9. One of them was the statement that " $\ldots$ if the surfaces are made smoother the friction will decrease and eventually approach zero as depicted" (9) in C10; the other was "The friction force depends on the surface area of the object" $(15,16)$ in C11 or the statement that "The bigger the surface, the bigger the friction coefficient" (4) in C12. Here, the relationship between the roughness of the surface and the friction, and the relationship between the size of the surface and the friction may be related, because a person who thinks that each different degree of roughness in a unit area will create separate friction may think that the roughness increases quantitatively, and that the resultant friction will increase as the area increases. The idea that "The bigger the surface, the bigger the friction coefficient" (4) was encountered in $\mathrm{C} 12$, while "the bigger the mass, the bigger the friction coefficient" (4) was encountered in C13. The reason for the emergence of these PMCs can be thought to be the misconception identified by Hapkiewicz that "Big objects exert a greater force than small objects." [68]. Also, friction is often understood at the macroscopic level, and as a result, students do not develop cognitive structures related to microscopic phenomena [69]. In a similar paper, Kurnaz and Ekşi also noted that most students think of friction as occurring at the macroscopic level and have difficulties conceptualizing it at the microscopic level [41].

\section{Theme 4: The effects of friction}

11 different PMCs about the effects of friction were encountered, from 13 papers. Three of them were related to energy transformation (D1, D2, and D3), four of them (D4, D5, D6, and D7) were related to causing or preventing 
TABLE V. PMCs related to the type and magnitude of friction.

\begin{tabular}{|c|c|c|c|}
\hline No. & $\mathrm{PMC}$ & Sample quotation & Paper No. \\
\hline $\mathrm{C} 1$ & $\begin{array}{l}\text { When the object moves; the kinetic friction } \\
\text { always acts between the contact areas. }\end{array}$ & $\begin{array}{l}\text { When the object moves; the kinetic friction always } \\
\text { acts between the contact areas [which are not } \\
\text { sliding each other]. (27) }\end{array}$ & 27 \\
\hline $\mathrm{C} 2$ & $\begin{array}{l}\text { Static friction is worth a minimum when the } \\
\text { object will start to move. }\end{array}$ & $\begin{array}{l}\text { Static friction is worth a minimum when the object } \\
\text { will start to move. (18) }\end{array}$ & 18 \\
\hline $\mathrm{C} 3$ & $\begin{array}{l}\text { Kinetic friction and rolling friction are } \\
\text { equivalent }\end{array}$ & $\begin{array}{l}\text { Kinetic friction and rolling friction are equivalent } \\
\text { designations for friction: the first one is used for } \\
\text { sliding objects, while the second one is used for } \\
\text { rolling objects. ( } 7 \text { ) }\end{array}$ & 7 \\
\hline $\mathrm{C} 4$ & $\begin{array}{l}\text { The static friction is always at the maximum } \\
\text { value } / \mu \mathrm{N} \text {. }\end{array}$ & $\begin{array}{l}\text { When a body remains at rest, frictional force always } \\
\text { acts on the body with its magnitude equals to } \\
\mathrm{f}_{\mathrm{f}}=\mu \mathrm{R} \text {. ( } 8 \text { ) } \\
\text { The static friction is always at the maximum value. } \\
\text { (31) }\end{array}$ & $8,12,31,32$ \\
\hline $\mathrm{C} 5$ & $\begin{array}{l}\text { Friction that occurs on an object at rest is } \\
\text { greater than the applied force. }\end{array}$ & $\begin{array}{l}\text {...magnitude of friction that occurs on an object [at } \\
\text { rest] is greater than the magnitude of force } \\
\text { deployed by someone who gives the force. (30) } \\
\text { However, they both maintained that the force was } \\
\text { smaller than friction when the car remained } \\
\text { stationary... (33) }\end{array}$ & 30,33 \\
\hline C6 & $\begin{array}{l}\text { Magnitude of static friction does not depend } \\
\text { on external force. }\end{array}$ & $\begin{array}{l}\text {... static friction ... [does not] varies in magnitude ... } \\
\text { depending on the external force. }(3)\end{array}$ & 3 \\
\hline $\mathrm{C} 7$ & $\begin{array}{l}\text { Coefficient of rolling friction depends on } \\
\text { moment inertia. }\end{array}$ & $\begin{array}{l}\text {...coefficient of rolling friction on a solid sphere is } \\
\text { smaller than a hollow sphere because the moment } \\
\text { inertia of a solid sphere is smaller than a hollow } \\
\text { sphere. (41) }\end{array}$ & 41 \\
\hline $\mathrm{C} 8$ & $\begin{array}{l}\text { If an object at rest begins to accelerate with } \\
\text { the effect of an external force, the friction } \\
\text { is greater than the external force. }\end{array}$ & $\begin{array}{l}\text { If there is a force of } 10 \mathrm{~N} \text { acting on a rest object on a } \\
\text { plane and the object moving with acceleration, this } \\
\text { means a friction of more than } 10 \mathrm{~N} \text { is acting on it. } \\
\text { (26) }\end{array}$ & 26 \\
\hline C9 & Friction depends on the interaction surface. & $\begin{array}{l}\text { Friction force depends on the interaction surface. } \\
\text { (19) }\end{array}$ & 19 \\
\hline $\mathrm{C} 10$ & $\begin{array}{l}\text { If the surfaces are made smoother the friction } \\
\text { will decrease. }\end{array}$ & $\begin{array}{l}\ldots \text { if the surfaces are made smoother the friction will } \\
\text { decrease and eventually approach zero as depicted. } \\
\text { (9) } \\
\text {...the relationship between roughness and friction is } \\
\text { linear. (11) }\end{array}$ & $9,10,11$ \\
\hline $\mathrm{C} 11$ & $\begin{array}{l}\text { Friction depends on the magnitude of the } \\
\text { contacting surfaces. }\end{array}$ & $\begin{array}{l}\text {...the larger the surface, the larger the friction force. } \\
\text { (4) The friction force depends on the surface area } \\
\text { of the object. }(15,16)\end{array}$ & $4,13,15,16,34$ \\
\hline $\mathrm{C} 12$ & $\begin{array}{l}\text { The bigger the surface, the bigger the friction } \\
\text { coefficient. }\end{array}$ & $\begin{array}{l}\text { The bigger the surface, the bigger the friction } \\
\text { coefficient. (4) }\end{array}$ & 4 \\
\hline $\mathrm{C} 13$ & $\begin{array}{l}\text { The bigger the mass, the bigger the friction } \\
\text { coefficient. }\end{array}$ & $\begin{array}{l}\text { The bigger the mass, the bigger the friction } \\
\text { coefficient. (4) }\end{array}$ & 4 \\
\hline
\end{tabular}

motion, and four of them (D8, D9, D10, and D11) were related to frictionless environments (Table VI).

The PMC detected in seven different papers, which was associated with hindering motion, was D4. The PMC detected in three different papers, which was associated with causing or hindering motion, was D7. All the other PMCs in this theme were determined by one paper each. It can thus be said that D4 and D7 were the most common PMCs in this theme.

"The energy lost during friction turns into heat" (20), related to D1; “... frictional forces are always associated with losses of mechanical energy" (39) related to D2; and "The presence of friction must affect the work done by you (even if you apply the same force over the same distance)" (31) related to D3 were encountered in terms of the role of friction in energy transformation. Sherwood and Bernard stated that the kinetic energy of an object moving at a constant speed on a frictional ground does not change, but the object warms up due to friction and increases its thermal energy. They stated that to solve this paradox, there should be expressions about different types of energy in the workenergy equation [70]. Most of the related statements are 
TABLE VI. PMCs related to the effects of friction.

\begin{tabular}{|c|c|c|c|}
\hline No. & PMC & Sample quotation & Paper No. \\
\hline D1 & $\begin{array}{l}\text { Friction always converts mechanical energy } \\
\text { into heat. }\end{array}$ & $\begin{array}{l}\text { The energy lost during friction turns into } \\
\text { heat. (20) }\end{array}$ & 20 \\
\hline D2 & $\begin{array}{l}\text { Friction is always associated with losses of } \\
\text { mechanical energy. }\end{array}$ & $\begin{array}{l}\ldots \text { frictional forces always is associated with } \\
\text { losses of mechanical energy. (39) }\end{array}$ & 39 \\
\hline D3 & $\begin{array}{l}\text { The presence of friction must affect the work } \\
\text { done by external force. }\end{array}$ & $\begin{array}{l}\text { The presence of friction must affect the work } \\
\text { done by you (even if you apply the same } \\
\text { force over the same distance). ( } 31 \text { ) }\end{array}$ & 31 \\
\hline D4 & Friction always hinders motion. & $\begin{array}{l}\text {... a sphere rolling without slipping across a } \\
\text { rigid and rough horizontal plane is ... } \\
\text { slowed by friction }(12)\end{array}$ & $12,14,22,25,31,35,38$ \\
\hline & & Friction always hinder motion. (31) & \\
\hline D5 & The effects of friction are always negative. & $\begin{array}{l}\ldots \text { friction almost exclusively as a } \\
\text { disturbance to be minimized... (3) }\end{array}$ & 3 \\
\hline D6 & $\begin{array}{l}\text { Kinetic friction is responsible for keeping the } \\
\text { object at rest on an incline. }\end{array}$ & $\begin{array}{l}\text { Kinetic friction is responsible for keeping the } \\
\text { car at rest on an incline. (31) }\end{array}$ & 31 \\
\hline D7 & Static friction does not cause motion. & $\begin{array}{l}\text {... the static friction force as a force that can } \\
\text { [not] produce motion. ( } 3 \text { ) } \\
\ldots \text { for any rolling object such as tire of a } \\
\text { vehicle or a ball, the only external force } \\
\text { that allow these objects to roll forward is } \\
\text { the forward friction. (5) }\end{array}$ & $3,5,7$ \\
\hline D8 & $\begin{array}{l}\text { Newton's laws are invalid in a frictionless } \\
\text { medium. }\end{array}$ & $\begin{array}{l}\ldots \text { There is no friction in space then this law } \\
{\left[F_{\text {net }}=\text { ma }\right] \text { is not valid in space. }(35)}\end{array}$ & 35 \\
\hline D9 & $\begin{array}{l}\text { Objects do not touch the ground on a } \\
\text { frictionless surface. }\end{array}$ & $\begin{array}{l}\ldots \text { without friction, the feet of the sleigh do } \\
\text { not touch the ground, so it goes in the air a } \\
\text { little [higher than the ground]. (24) }\end{array}$ & 24 \\
\hline D10 & $\begin{array}{l}\text { Round objects on a frictionless inclined plane } \\
\text { do not slide without rolling. }\end{array}$ & $\begin{array}{l}\text {.. a sphere on a frictionless inclined plane } \\
\text { [does not] slides without rolling. (12) }\end{array}$ & 12 \\
\hline D11 & $\begin{array}{l}\text { Balance cannot be maintained on frictional } \\
\text { surfaces. }\end{array}$ & $\begin{array}{l}\text {...balance cannot be maintained on frictional } \\
\text { surfaces. }(38)\end{array}$ & 38 \\
\hline
\end{tabular}

pejorative and attribute negative characteristics to friction. The statement that "Friction always hinders motion" (31) can be interpreted in this light. On the other hand, D6, which emerged from confusing kinetic friction and static friction, is represented by the statement "Kinetic friction is responsible for keeping the car at rest on an incline" (31). Ignoring the effect of static friction on the motion encountered in theme 3 finds expression in the statement that "... the static friction force as a force that can(not) produce motion" (3) in D7. Develi and Namdar investigated the definitions of friction force in 26 textbooks [2]. They found that when explaining friction force, the textbooks studied used the concept of motion to define or explain friction force, while the idea of sliding was used to describe situations where friction is encountered in everyday life. When friction force is defined using the concept of motion, it is mostly expressed as a force that hinders motion. They thus concluded that referring to the concept of motion might not be a suitable choice when describing friction force.

It is noteworthy that D8 was encountered in a paper. The related statement was as follows: “... There is no friction in space then this law $\left(\mathrm{F}_{\text {net }}=\mathrm{ma}\right)$ is not valid in space." (35). Following this, the statement that "... without friction, the feet of the sleigh do not touch the ground, so it goes in the air a little." (24) was encountered in D9, and the statement that "... balance cannot be maintained on frictional surfaces" (38) was encountered in D11. It is noteworthy that all these statements were obtained from papers conducted in the same country. On the other hand, a similar PMC, D10 from a different country is expressed in the idea that "... a sphere on a frictionless inclined plane (does not) slides without rolling." (12) regarding spherical objects.

Individuals in the research's target groups often ignored the distinction between sliding and rolling friction. Although various studies, e.g., Refs. [71,72], have been conducted to teach students about friction in rolling motion, there is no paper investigating the reasons for ignoring this distinction. On the other hand, the issue of rolling friction is an issue that has not been adequately researched yet. For example, "for sliding friction, the Amontons-Coulomb law clearly states the proportionality between the friction and the normal force, the rolling friction torque and normal force dependency is assumed linear in some references and 
nonlinear in others" [73]. This situation may cause teachers to hesitate to teach this topic in detail and may explain why it has been ignored; it can be a difficult topic to learn.

\section{B. Relationship between bibliometrics of papers and PMCs with themes}

When the notion of conducting a study on misconceptions arose, it seemed that the literature might already be well served and even saturated by studies of this nature. Ecevit and Şimşek, two of the researchers who hold this view, found that the number of studies on misconceptions had decreased in recent years, and they attributed this decrease to there being enough studies on misconceptions [74]. However, the fact that 15 of the 42 papers on the friction accessed in this study were published in the last five years shows that the studies of misconceptions continue today. In addition, in most of the papers, friction appears as a subproblem, not a direct research problem [6]. In the current study, only 16 out of 42 papers were about friction directly.

\section{The locales on the papers}

The locale on papers varies for some PMCs (A1, A7, B1, B2, B3, B4, C4, C5, C11, D4, and D7). The other 31 PMCs were detected in single countries. Some have even been diagnosed in more than one paper in the same country.

It can be said that PMCs detected in different locations exist independently of culture. However, it cannot be known whether those detected in single countries are independent of culture. Therefore, it should be investigated whether PMCs detected in only one country are also seen in other countries. It is known that some misconceptions arise depending on the culture and the daily language in that region [3,5]. Such PMCs are local and can be tried to remediate linguistically and culturally. However, this does not apply to those who are independent of culture.

\section{The sample levels on the papers}

It can be said that the sample levels on the papers reviewed in this study range from elementary school level to teachers. However, the distribution of sample levels is not homogeneous. The most common sample level in papers were undergraduate students. Elementary school students, graduate students, and teachers were included in a small number of papers. Preschool students were not included in any paper. Based on the themes, the most common sample level for each theme is undergraduate students. No elementary school students and graduate students were included in the papers within theme 1 and theme 2. In addition, no teachers were included in the papers in theme 2 .

Canlas also examined the literature to determine preconceptions related to friction and found that most of the existing studies on the subject were at the undergraduate level [6]. This was also the case in other studies $[7,8]$ that reviewed various educational journals that are indexed in the social sciences citation index. In a study examining some journals with high impact factors, it was determined that half of the articles in the journals were conducted with elementary school and high school students, and the other half with teachers and undergraduate students [9]. While similar results determined in these four studies published in four different education journals reveal the research tendencies of the educators, it is still unexpected for this study of PMCs. Since friction is involved as a curricular topic at all levels of education up to university, it is surprising that it has never been studied with preschoolers. Misconceptions do not have only one period of education and can continue throughout life, starting from preschool [74]. As a matter of fact, in the papers reviewed in this study, it was seen that some PMCs existed at a single education level, while some PMCs existed at more than one education level, and even among teachers.

\section{The data collections on the papers}

When the data collection techniques or tools on the papers were evaluated, it was seen that there were two issues in general. The first is related to the selection of data collection techniques or tools on the papers, and the other is related to the fact that friction force is not included as a research topic on its own in the studies. These two issues are described below:

The most common data collection techniques or tools on the papers reviewed in this study were, in order of frequency: interviews, multiple-choice tests, multiple-tier tests, and open-ended tests. When the themes are taken as a basis, even though the rankings have changed, multiplechoice tests took place more than multiple-tier tests in all themes except for theme 2. In theme 2, drawing tests outweighed multiple-choice and multiple-tier tests. The reason for this situation is that theme 2 is related to the direction of the friction. In this respect, the results of the studies we have been able to reach, regarding the selection of data collection techniques or tools in the literature are as follows: Canlas examined previous studies and presented the probing strategies used in determining preconceptions of students about friction in a table. According to this table, multiple-choice assessments and interviews were mostly included in the studies, respectively. Open-ended questions, problem-setting questions, and multiple-tier questions follow with equal frequency [6]. Soeharto, Csapó, Sarimanah, Dewi, and Sabri investigated the diagnostic tools in 111 articles published from 2015 to 2019 [75]. They found that the most common diagnostic tools were, in order of frequency, multiple-tier tests, ordinary multiple-choice tests, open-ended tests, and interviews. Kaltakçı-Gürel, Eryılmaz, and McDermott stated the order of frequency as interviews, then open-ended tests, multiple-choice tests, and, finally, multiple-tier tests [10]. Also, Yavuz examined 
64 master's and doctoral theses related to misconceptions and stated that conceptual understanding tests and interviews were used the most in these theses [76]. Many tools (multiple-choice tests, multiple-tier diagnostic tests, drawings, word association tests, concept inventories, online diagnostic tests, open questionnaires) or techniques (clinical interviews, observation, concept maps, structured communication grid, mind maps, role-playing, card sorts, models, apparatus) can be used to determine misconceptions [55]. Some of these were used in the papers reviewed here and studies mentioned above too. On the other hand, Kaltakç1Gürel, Eryılmaz, and McDermott state that studies focusing on conceptual understanding and methods to diagnose misconceptions validly and reliably have great importance [10]. Although there is no consensus in the literature on which technique or tool is the best in determining misconceptions, there are studies that summarize the strengths and weaknesses of interviews, open-ended tests, ordinary multiple-choice tests, and multiple-tier multiple-choice tests $[10,75]$. When these studies are examined, although the interviews have many weaknesses (need specific skills to conduct interviews, interviews' data analysis is difficult and subjective, etc.), they will be successful in measuring the misconceptions if they are structured correctly because they have significant strengths (provides in-depth explanation data, the flexibility of item questions, etc.). In these studies, it is also seen that multiple-tier multiple-choice tests have all the strengths of ordinary multiple-choice tests (provides time efficiency, objectively scored, etc.), and in addition to these strengths, additional strengths (provides an opportunity to assess the proposition of student reasoning, truly assesses misconceptions which are free of errors and lack of knowledge, etc.) are added as the number of stages increases. Since multiple-tier tests have significant strengths, their preference in identifying misconceptions will strengthen the determination of misconceptions. Because of the nature of misconceptions, considering the strengths and weaknesses of data collection techniques or tools, it would be more appropriate to use those that minimize randomness. From this perspective, while it is a positive situation that the papers examined in this research have the most interviews among the data collection tools, it can be considered as a negative situation that the number of multiple-tier tests is equal to multiple-choice tests. In addition, the low number of three-tier tests and four-tier tests can be considered as a negative situation.

When evaluating how friction was included in the data collection techniques or tools of the papers, it was seen that the techniques or tools used in the papers were extensive and generally contained only a limited number of questions about friction. This can be explained by Canlas' comment that in most studies that diagnosed students' misconceptions, friction is not a direct research problem but a subproblem [6]. Multiple-tier tests have been developed on various topics [20,77-80]. However, no test has been found in the literature about friction alone. The fact that friction was included in only a few questions in the data collection techniques or tools indicates that the contents of friction were considered very narrowly in the papers. The essential point that should be considered here is how well the technique or tool used can detect conceptual responses. In their study, Ecevit and Şimşek investigated how teachers detected their students' misconceptions; the answer was mostly through discussions during the lesson [74]. However, they stated that the discussions were kept as short as possible and avoided any issues that would require a longer duration to explain. Failure to use an appropriate technique or tool for the detection of misconceptions will not provide precise information about what kind of cognitive structures individuals have, and it will become controversial whether undesirable situations in these structures arise from misconceptions or conceptual confusion.

\section{CONCLUSION}

This study reviewed papers in the literature that included PMCs about solid friction and classified the detected PMCs thematically. This classification brought to the foreground four different themes that need to be addressed in the teaching of friction: the definition and existence of friction, the direction of friction, the type and magnitude of friction, and the effects of friction. Most of the PMCs were in the type and magnitude theme and the least are in the direction theme. But friction is always opposite to the direction of the motion as a PMC was detected in the highest number of papers. Related to this, the PMC that friction prevents movement was frequently encountered. It was also found that both the distinction between sliding and rolling friction and kinetic and static friction was often ignored.

To conclude, the techniques or tools used for detecting these PMCs were usually interviews, multiple-choice tests, multiple-tier tests, and open-ended tests. One of the remarkable findings of this study is that measurement tools that measure behavior, especially the multiple-choice tests developed to determine the individual's scientific knowledge, are also used to diagnose misconceptions, which is a type of cognitive knowledge. However, considering that scientific knowledge and misconceptions are different cognitive structures, how effective measurement tools that measure behavior are in detecting misconceptions is a separate issue. Also, the fact that the same PMCs occurred in countries where different languages were spoken is an interesting finding of the study.

Considering the effects of the research results on the learning environment, thematic classification of the PMC related to friction supports the gains in curriculums. For example, in the physics curriculum used in Turkey [46], "the static and kinetic friction forces are compared, the direction of the friction force in sliding and rotating objects is explained with examples" are included in the explanation of the outcomes related to friction while one of the 
Canadian, Ontario physics curriculum outcomes is "analyze the force of friction, coefficient of static friction, and coefficient of kinetic friction" are included [45]. In line with these detailed explanations in the curriculums, it can be considered that the thematic classification lists obtained as a result of the study will help to better understand the subject of friction by the students. One of the most important tasks of teachers in the learning process is to identify the intuitions or alternative concepts that students have already acquired about friction. These intuition and alternative concepts in the minds of students prevent meaningful learning of the subject of friction. PMCs and methods of detecting PMCs obtained as a result of the study will help teachers in this process. In addition, one of the results of the study is that PMCs are not only in the students but also determined in teachers and preservice teachers. In this respect, the results of the study may also be considered in terms of the direction of teachers in in-service training studies.

\section{A. Limitations}

This study's scope is limited to the dry friction caused by the relative motion of two solid bodies against each other, for which classical friction models are valid. The fact that other studies in the literature may not have been included or may have been overlooked due to database and key word selection, since only publications written in Turkish and English were included are limitations of this study.

When using the classical friction models of Amontons and Coulomb, these models will not be valid in some cases, because they performed their limited number of experiments using a limited number of materials (e.g., metal and wood), and for a limited number of conditions (e.g., sliding friction of solids). Many materials such as wood, ceramics, and metals do conform to the classical friction model [81]. On the other hand, many materials, such as flexible materials, diamonds, polymers, Teflon, and rocks, do not comply with these general principles [82]. Some may differ by friction surface area, others by velocity. This study has identified such exceptional cases as limitations.

\section{B. Suggestions}

This study did not consider the differences between scientific errors and misconceptions. All the PMCs found in the literature were included in the study. Using the thematic PMC list that emerged in this study will be beneficial in unearthing real misconceptions, which are not simple mistakes or lack of knowledge, and investigating their underlying causes.

Many PMCs regarding friction at both the macroscopic and microscopic levels are listed. These PMCs do not appear only in students. Also, teachers and teacher candidates have these PMCs. As suggested by Kurnaz and Ekşi, it may be helpful to evaluate how it is currently taught before looking for new ways to teach friction at both microscopic and macroscopic aspects [41].
The diversity of misconceptions and their relations with each other are considerable. Although the type and magnitude of friction, which is one of the inductively created themes in this study, was not encountered in previous classifications, it corresponds to $31 \%$ of the PMCs reached in this study. It may be beneficial for researchers and teachers who will study friction to consider this situation.

Many tests related to various concepts in physics have been developed and they are used in much research. Among these tests, those related to force, motion, and mechanics may also include the concept of friction. The Force Concept Inventory [83], the Force and Motion Conceptual Evaluation [84], the Mechanic Baseline Test [85], and the Two-Tier Physics Questionnaire [86] can be given as examples of these. Although these tools have been tested in many papers, they are mixed tests that try to diagnose many related concepts at the same time rather than focusing on a specific concept. So, their validity in determining conceptual processes is a matter of debate. This study has revealed that there are already many PMCs about friction. It is not possible to include all these PMCs in mixed tests. Therefore, it would be beneficial to prepare more reliable and valid diagnostic tests by considering each theme separately. For this, a measurement tool should be used that can consistently examine the process of misconceptions as interviews and multiple-tier tests.

\section{ACKNOWLEDGMENTS}

The preliminary analyses of this study were delivered as an oral presentation at a congress and published as an abstract [87]. We would like to thank Volkan Damlı and Gülnur Önsal for their contribution to the preliminary study.

\section{APPENDIX: LIST OF REVIEWED PAPERS}

We analyzed previous papers on PMCs in this study. Readers may require the sources of the findings. Therefore, these papers are listed below.

1. Ameh, C. O. \& Gunstone, R. F. (1988). The understanding held by Nigerian science teachers of some science concepts. Paper presented at the Annual Meeting of the American Educational Research Association, New Orleans, LA.

2. Aviani, I., Erceg, N., \& Mešić, V. (2015). Drawing and using free body diagrams: Why it may be better not to decompose forces. Physical Review Special Topics-Physics Education Research, 11(2), 020137. https://doi.org/ 10.1103/PhysRevSTPER.11.020137.

3. Besson, U., Borghi, L., De Ambrosis, A. \& Mascheretti, P. (2010). A three-dimensional approach and open source structure for the design and experimentation of teaching-learning sequences: The case of friction. International Journal of Science Education, 32(10), 12891313. https://doi.org/10.1080/09500690903023350. 
4. Bilal, E. \& Erol, M. (2010). Hypothesis-ExperimentInstruction (HEI) method for investigation and elimination of misconceptions on friction. Balkan Physics Letters, 18, 269-276.

5. Canlas, I. P. (2019). Using visual representations in identifying students' preconceptions in friction, Research in Science \& Technological Education. https://doi.org/ 10.1080/02635143.2019.1660630.

6. Cari, C., Wulandari, P. S., Aminah, N. S., Handhika, J., \& Nugraha, D. A. (2019). Students' understanding level of friction force direction concept on rolling object. Journal of Physics: Conference Series, 1153, 1, 012150. https:// doi.org/10.1088/1742-6596/1153/1/012150.

7. Carvalho, P. S. \& Sousa, A. S. (2005). Rotation in secondary school: teaching the effects of frictional force. Physics Education, 40(3), 257-265. https://doi.org/ 10.1088/0031-9120/40/3/007.

8. Chia, T. C. (1996). Common misconceptions in frictional force among university physics students. Teaching and Learning, 16(2), 107-116. https://repository.nie. edu.sg/handle/10497/434.

9. Corpuz, E. G. \& Rebello, N. S. (2006). Students' conceptual development in the context of microscopic friction: a case study with two students. Proceedings of the NARST 2006 Annual Meeting, April 3-6, San Francisco, CA.

10. Corpuz, E. D., \& Rebello, N. S. (2011a). Investigating students' mental models and knowledge construction of microscopic friction. I. Implications for curriculum design and development. Physical Review Special Topics-Physics Education Research, 7(2), 020102. http://doi.org/10.1103/PhysRevSTPER.7.020102.

11. Corpuz, E. D., \& Rebello, N. S. (2011b). Investigating students' mental models and knowledge construction of microscopic friction. II. Implications for curriculum design and development. Physical Review Special Topics-Physics Education Research, 7(2), 020103. http://doi.org/10.1103/ PhysRevSTPER.7.020103.

12. De Ambrosis, A., Malgier, M., Mascheretti, P. \& Onorato, P. (2015) Investigating the role of sliding friction in rolling motion: a teaching sequence based on experiments and simulations, European Journal of Physics, 36, 035020, http://doi.org/10.1088/0143-0807/36/3/ 035020 .

13. Dixon, S. J. (2005). Diagnostic assessment of preparedness of level one sports science students for biomechanics modules. International Journal of Mathematical Education in Science and Technology, 36(1), 49-63. https://doi.org/10.1080/00207390412331303748.

14. Ergün, H. (2016). Adaptation of a diagnostic test about rotational and rolling motion concepts into turkish and its application. Yüzüncü Yll University Journal of Education Faculty, 13(1), 411-442. [in Turkish].

15. Hançer, A. H. \& Durkan, N. (2008). Turkish pupils understanding of physical concept: Force and movement. World Applied Sciences Journal, 3(1), 45-50.
16. Hançer, A. H. (2007). Fen eğitiminde yapılandırmacı yaklaşıma dayalı bilgisayar destekli öğrenmenin kavram yanılgıları üzerine etkisi [The effect of computer aided learning based upon constructivist approach in science education on misconceptions]. Cumhuriyet University Journal of Social Sciences, 31(1), 69-81. [in Turkish].

17. Handhika, J., Cari, Suparmi, \& Sunarno, W. (2015). External representation to overcome misconception in physics. International Conference on Mathematics, Science, and Education, Semarang, Indonesia.

18. Kaniawati, I., Fratiwi, N. J., Danawan, A., Suyana, I., Samsudin, A., \& Suhendi, E. (2019). Analyzing students' misconceptions about Newton's laws through four-tier Newtonian test (FTNT). Journal of Turkish Science Education, 16(1), 110-122.

19. Kara, İ. (2007). Revelation of general knowledge and misconceptions about Newton's law of motion by drawing method. World Applied Sciences Journal, 2(S), 770-778.

20. Kızılcık, H. Ş. \& Tan, M. (2018). A qualitative research of the conceptual learning process of the heat concept. Asia-Pasific Forum on Science Learning and Teaching, 19(1), Article 14.

21. Kruger, C., Palacio, D. \& Summers, M. (1992). Surveys of English primary school teachers' conceptions of force, energy and materials. Science Education, 76(4), 339-351. https://doi.org/10.1002/sce.3730760402.

22. Kurnaz, M. A., \& Ekşi, C. (2015). An analysis of high school students' mental models of solid friction in physics. Educational Sciences: Theory \& Practice, 15(3), 787-795. http://doi.org/10.12738/estp.2015.3.2526.

23. Kurt, Ş. \& Akdeniz, A. R. (2003). Farkl1 düzeylerdeki öğrencilerde kuvvet kavramı ile ilgili yanilgilar [Misconceptions about the concept of force in students at different levels]. $12^{\text {th }}$ Congress of Educational Sciences, 15-18 October, Antalya. [in Turkish].

24. Nuhoğlu, H. (2008). Evaluation of the secondary school pupils' view about force and motion. Inönü University Journal of the Faculty of Education, 9(16), 123-140. [in Turkish].

25. Özden. B. \& Yenice, N. (2017). Developing three-tier conceptual understanding test towards "force and energy" unit. Necatibey Faculty of Education Electronic Journal of Science and Mathematics Education, 11(2), 432-463. [in Turkish] https://doi.org/10.17522/balikesirnef.373421.

26. Panprueksa, K., N. Phonphok, M., Boonprakob, \& Dahsah, C. (2012). Thai students' conceptual understanding on force and motion. International Conference on Education and Management Innovation. Singapore: IACSIT Press. http://www.ipedr.com/vol30/54-ICEMI\% 202012-M10050.pdf.

27. Prasitpong, S. \& Chitaree, R. (2009). What Thai students think about directions and types of frictional forces. International Conference of Physics Education (ICPE2009), AIP Conference Proceedings Book, 66-69. https://doi.org/10.1063/1.3479895. 
28. Prasitpong, S., Chitaree, R., \& Rakkapao, S. (2010). Studying the frictional force directions via bristles. Physics Education, 45(6), 602-610. https://doi.org/10.1088/00319120/45/6/004.

29. Sağlam, Y., Kanadlı, S., \& Uşak, M. (2012). The impacts of context on students' use of concept images. Journal of Turkish Science Education, 9(4), 131-145. [in Turkish].

30. Sari, D. R., Ramdhani, D., \& Surtikanti, H. K. (2019). Analysis of elementary school students' misconception on force and movement concept. Journal of Physics: Conference Series, 1157, 2, 022053. https:// doi.org/10.1088/1742-6596/1157/2/022053.

31. Singh, C. (2007). Effect of misconception on transfer in problem solving. Physics Education Research Conference, August 1-2, Greensboro NC, 951, 196-199. https://doi.org/10.1063/1.2820931.

32. Steif, P. \& Hansen, M. (2006). Comparisons between performances in a statics concept inventory and course examinations. International Journal of Engineering Education, 22(5), 2006, 1070-1076.

33. Tao, P. \& Gunstone, R. F. (1999). The process of conceptual change in force and motion during computersupported physics instruction. Journal of Research in Science Teaching, 36 (7), 859-882. https://doi.org/ 10.1002/(SICI)1098-2736(199909)36:7<859::AID-TEA7> 3.0.CO;2-J.

34. Temiz, B. K. \& Kızılcık, H. Ş. (2016). Sürtünmeli eğik düzlemde hareketin dinamiğine ilişkin öğrenci düşünceleri [Student opinions about dynamics of motion on friction inclined plane]. Journal of Research in Education and Society, 3(2), 15-30. [in Turkish].

35. Temiz, B. K. \& Yavuz, A. (2014). Students' misconceptions about Newton's second law in outer space.
European Journal of Physics, 35, 045004. https://doi.org/ 10.1088/0143-0807/35/4/045004.

36. Trumper, R. \& Gorsky, P. (1996). A cross-college age study about physics students' conceptions of force in preservice training for high school teachers. Physics Education, 31(4), 227-236. https://doi.org/10.1088/00319120/31/4/021.

37. Trumper, R. \& Gorsky, P. (1997). A survey of biology students' conceptions of force in pre-service training for high school teachers. Research in Science \& Technological Education, 15(2). https://doi.org/10.1080/ 0263514970150201.

38. Turgut, Ü., Alptekin, T., \& Altun, S. (2007). High school second grade students' misconceptions of Newton's first and third laws. Bayburt Journal of Educational Faculty, 2(2), 164-178. [in Turkish].

39. Vidak, A., Ercek, N., Hasovic, E., Odzak, S., \& Mesic, M. (2018). Teaching about rolling motion: exploring the effectiveness of an extreme case reasoning approach. Journal of Baltic Science Education, 17(3), 511-524.

40. Wulandari, P. S., Cari, C., \& Aminah, N. S. (2017). Student's conception about friction force direction in physics education. Journal of Physics: Theories and Applications, 1(2), 97-107. http://doi.org/10.20961/jphystheor-appl.v1i2.19122.

41. Wulandari, P. S., Cari, C., Aminah, N. S., \& Nugraha, D. A. (2018). Pre-service teachers' conceptual understanding of rolling friction coefficient. AIP Conference Proceedings, 2014, 1, 020060. https:// doi.org/10.1063/1.5054464.

42. Yıldız, A. \& Büyükkasap, E. (2006). Misconceptions of the students in the department of physics about force and motion subjects and the conjecture of the teaching staff on this matter. Hacettepe University Journal of Education, 30, 268-277. [in Turkish].
[1] J. E. Ormrod, Educational Psychology: Developing Learners, 5th ed. (Pearson Prentice Hall, Upper Saddle River, NJ, 2006).

[2] F. Develi and B. Namdar, Defining friction force: A proposed solution to a textbook problem, J. Educ. Sci. Environ. Health 5, 91 (2019).

[3] A. İ. Şen and A. R. Akdeniz, Teaching Physics (Pegem Akademi, Ankara, 2017) [In Turkish].

[4] J.G. Brooks and M. G. Brooks, In Search of Understanding: The Case for Constructivist Classroom (Association for Supervision and Curriculum Development, Alexandria, VA, 1999).

[5] Misconceptions in Physics, edited by B. Güneş (Palme, Ankara, 2017) [in Turkish].
[6] I. P. Canlas, Using visual representations in identifying students' preconceptions in friction, Res. Sci. Technol. Educ. 39, 156 (2021).

[7] H. Doğan and T. N. Tok, Analysis of the articles published in the field of educational sciences in Turkey: An example of education and science journal, Curr. Res. Educ. 4, 94 (2018).

[8] Y. Göktaş, S. Küçük, M. Aydemir, E. Telli, Ö. Arpacık, G. Yıldırım, and I. Reisoğlu, Türkiye'de eğitim teknolojileri araştırmalarındaki eğilimler: 2000-2009 dönemi makalelerinin içerik analizi [Research trends in educational technology in Turkey: Content analysis of the articles on 2000-2009 term, Educ. Sci. Theory Pract. 12, 177 (2012)]. 
[9] S. Yalçın, H. Ç. Yavuz, and M. İ. Dibek, Content analysis of papers published in educational journals with high impact factors, Educ. Sci. 40, 1 (2016).

[10] D. Kaltakçı-Gurel, A. Eryilmaz, and L. C. McDermott, A review and comparison of diagnostic instruments to identify students' misconceptions in science, Eurasia J. Math. Sci. Technol. Educ. 11, 989 (2015).

[11] P. H. Scott, H. M. Asoko, and R. H. Driver, Teaching for conceptual change: A review of strategies, in Research in Physics Learning: Theoretical Issues and Empirical Studies Proceedings of an International Workshop (Institute of Science Education, Kiel, 1991), pp. 310-329.

[12] J. Clement, Using bridging analogies and anchoring intuitions to deal with students' preconceptions in physics, J. Res. Sci. Teach. 30, 1241 (1993).

[13] J. K. Gilbert and D. M. Watts, Concepts, misconceptions and alternative conceptions. Changing perspectives in science education, Studies Sci. Educ. 10, 61 (1983).

[14] A. Vaughn, Targeting students' science misconceptions: Physical science activities using the conceptual change model, School Sci. Math. 97, 54 (1997).

[15] R. Yağbasan and Ç. Gülçiçek, Describing the characteristics of misconceptions in science teaching, Pamukkale Univ. J. Educ. 1, 102 (2003).

[16] P. Potvin, L. Nenciovici, G. Malenfant-Robichaud, F. Thibault, O. Sy, M. A. Mahhou, A. Bernard, G. AllaireDuquette, J. B. Sarrasin, L. M. B. Foisy, N. Brouillette, A. A. St-Aubin, P. Charland, S. Masson, M. Riopel, C. C. Tsai, M. Bélanger, and P. Chastenay, Models of conceptual change in science learning: establishing an exhaustive inventory based on support given by articles published in major journals, Studies Sci. Educ. 56, 157 (2020).

[17] A. Eryılmaz and E. Sürmeli, Üç-aşamalı sorularla öğrencilerin 1sı ve sıcaklık konularındaki kavram yanılgılarının ölçülmesi [Measuring students' misconceptions about heat and temperature with three-tier questions], in V. Ulusal Fen Bilimleri ve Matematik Eğitimi Kongresi [5th National Science and Mathematics Education Congress] proceedings, Ankara, Turkey (ODTU, Ankara, 2002).

[18] R. J. Osborne and J. K. Gilbert, A technique for exploring the students' view of the world, Phys. Educ. 15, 376 (1980).

[19] R. J. Beichner, Testing student interpretation of kinematics graphs, Am. J. Phys. 62, 750 (1994).

[20] I. S. Caleon and R. Subramaniam, Development and application of a three-tier diagnostic test to assess secondary students' understanding of waves, Int. J. Sci. Educ. 32, 939 (2010).

[21] H. Peşman and A. Eryılmaz, Development of a three-tier test to assess misconceptions about simple electric circuits, J. Educ. Res. 103, 208 (2010).

[22] D. F. Treagust, Evaluating students' misconceptions by means of diagnostic multiple-choice items, Res. Sci. Educ. 16, 199 (1986).

[23] E. D. Corpuz and N. S. Rebello, Investigating students' mental models and knowledge construction of microscopic friction. I. Implications for curriculum design and development, Phys. Rev. ST Phys. Educ. Res. 7, 020102 (2011).

[24] C. Angell, Ø. Guttersrud, E. K. Henriksen, and A. Isnes, Physics: frightful, but fun. Pupils' and teachers' views of physics and physics teaching, Sci. Educ. 88, 683 (2004).
[25] S. Gebbels, S. M. Evans, and L. A. Murphy, Making science special for pupils with learning difficulties, British Journal of special education 37, 139 (2010).

[26] C. Williams, M. Stanisstreet, K. Spall, E. Boyes, and D. Dickson, Why aren't secondary students interest in physics?, Phys. Educ. 38, 324 (2003).

[27] N. Önder, Ö. Oktay, F. Eraslan, Ç. Gülçiçek, V. Göksu, U. Kanlı, A. Eryılmaz, and B. Güneş, Content analysis of physics education studies published in Turkish science education journal from 2004 to 2011, J. Turkish Sci. Educ. 10, 151 (2013).

[28] U. Kanlı, Ç. Gülçiçek, V. Göksu, N. Önder, Ö. Oktay, F. Erarslan, A. Eryılmaz, and B. Güneş, Content analysis of physics education studies published in National Science and Mathematics Education Congress proceedings, Gazi University J. Educ. Faculty 34, 127 (2014).

[29] Y. Chang, C. Chang, and Y. H. Tseng, Trends of science education research: An automatic content analysis, J. Sci. Educ. Technol. 19, 315 (2010).

[30] B. Kiras, Trend in topics and methodological analysis of theses on science education in Turkey, Ph.D. thesis, Abant İzzet Baysal University, Bolu, 2019 (to be published).

[31] M. Lee, Y. Wu, and C. Tsai, Research trends in science education from 2003 to 2007: A content analysis of publications in selected journals, Int. J. Sci. Educ. 31, 1999 (2009).

[32] C. Tsai and M. L. Wen, Research and trends in science education from 1998 to 2002: a content analysis of publication in selected journals, Int. J. Sci. Educ. 27, 3 (2005).

[33] P. Mulhall and R. Gunstone, Views about learning physics held by physics teachers with differing approaches to teaching physics, J. Sci. Teach. Educ. 23, 429 (2012).

[34] E. E. Cevik and M. A. Kurnaz, Analysis of the responses of science teacher candidates to force concept inventory by concentration factor, Universal J. Educ. Res. 7, 111 (2019).

[35] J. Harris, N. R. George, K. Hirsh-Pasek, and N. S. Newcombe, Where will it go? How children and adults reason about force and motion, Cognit. Dev. 45, 113 (2018).

[36] O. Kahveci and K. Kantarl1, The effect of introductory physics course on the conceptual understanding of Newtonian mechanics of the first-year undergraduate students, Anadolu Univ. J. Sci. Technol. 9, 41 (2008).

[37] G. Poutot and B. Blandin, Exploration of students' misconceptions in mechanics using the FCI, Am. J. Educ. Res. 3, 116 (2015).

[38] A. Savinainen and P. Scott, Using the Force Concept Inventory to monitor student learning and to plan teaching, Phys. Educ. 37, 53 (2002).

[39] S. Şahin and O. Karamustafaoğlu, The images of primary school students on force and motion concepts, Turkish J. Teach. Educ. 5, 49 (2016).

[40] D. Şimşek, M. T. Yurtcan, and Ö. Oktay, Science teacher candidates' misconceptions on force and motion subjects, Erzincan University J. Educ. Faculty 21, 195 (2019).

[41] M. A. Kurnaz and C. Eksi, An analysis of high school students' mental models of solid friction in physics, Educ. Sci. Theory Pract. 15, 787 (2015). 
[42] E. D. Corpuz, Students' modeling of friction at the microscopic level, Ph.D. thesis, Kansas University, Lawrence, KS, 2006, http://web.phys.ksu.edu/dissertations/corpuz_ phd_2006.pdf.

[43] E. Popova and V.L. Popov, The research works of Coulomb and Amontons and generalized laws of friction, Friction and wear in machinery 3, 183 (2015).

[44] National Council for Curriculum and Assessment [NCCA], Leaving certificate physics syllabus. Retrieved from https:// www.curriculumonline.ie/getmedia/a789272e-823f-4d40b095-4ff8f6f195e4/SCSEC27_Physics_syllabus_eng.pdf (2018).

[45] Ontario Ministry of Education, The Ontario curriculum, grades 11 and 12. Retrieved from http://www.edu.gov.on.ca/ eng/curriculum/secondary/2009science11_12.pdf (2008).

[46] Ministry of National Education [MoNE], Ortaöğretim fizik dersi (9., 10., 11. ve 12. siniflar) öğretim programı [Secondary education $(9,10,11$ and 12th grade) physics course curriculum]. Board of Education, Ankara. http:// mufredat.meb.gov.tr/ProgramDetay.aspx?PID=351 (2018).

[47] E. D. Corpuz and N.S. Rebello, Investigating students' mental models and knowledge construction of microscopic friction. II. Implications for curriculum design and development, Phys. Rev. ST Phys. Educ. Res. 7, 020103 (2011).

[48] F. D. Hepdoğru, Ortaöğretim Fizik 9. Sinıf Ders Kitabı [Secondary Education Physics 9th Grade Textbook] (Tutku Publishing, Ankara, 2018).

[49] R. A. Serway and R. J. Beichner, Fen ve mühendislik için fizik $\iota$ : mekanik, mekanik dalglar, termodinamik [Physics for scientists and engineers with modern physics translation from the 5th ed.], edited by Kemal Çolakoğlu (Palme Publishing, Ankara, 2012).

[50] H. D. Young and A. R. Freedman, Sears ve Zemansky'nin üniversite fiziği cilt I [Sear's and Zemansky's university physics with modern physics translation from the 12th ed.], edited by Hilmi Ünlü (Pearson, İstanbul, 2013).

[51] B. Özden and N. Yenice, Developing three-tier conceptual understanding test towards "force and energy" unit, Necatibey Faculty of Educ. Electronic J. Sci. Math. Educ. 11, 432 (2017).

[52] A. Hançerand N. Durkan, Turkish pupils understanding of physical concept: Force and movement, World Applied Sci. J. 3, 45 (2008).

[53] A. Yıldız and E. Büyükkasap, Misconceptions of the students in the department of physics about force and motion subjects and the conjecture of the teaching staff on this matter, Hacettepe Univ. J. Educ. 30, 268 (2006).

[54] L. S. Shulman, Those who understand: Knowledge growth in teaching, Educ. Res. 15, 4 (1986).

[55] S. J. Patil, R. L. Chavan, and V. S. Khandagale, Identication of misconceptions in science: tools, techniques \& skills for teachers, Aarhat Multidisc. Int. Educ. Res. J. VIII, 466 (2019).

[56] D. Tranfield, D. Denyer, and P. Smart, Towards a methodology for developing evidence informed management knowledge by means of systematic review, British J. Management 14, 207 (2003).

[57] J. Webster and R. T. Watson, Analyzing the past to prepare for the future: Writing a literature review, Management Information Systems Quarterly 26, 13 (2002).
[58] H. Snyder, Literature review as a research methodology: An overview and guidelines, Journal of business research 104, 333 (2019).

[59] A. Yıldırım and H. Şimşek, Sosyal bilimlerde nitel araştırma yöntemleri [Qualitative research methods in the social sciences] (Seçkin Publishing, Ankara, 2008).

[60] J. Landis and G. Koch, The measurement of observer agreement for categorical data, Biometrics 33, 159 (1977).

[61] C. A. Wynd, B. Schmidt, and M. A. Schaefer, Two quantitative approaches for estimating content validity, Western J. Nursing Res. 25, 508 (2003).

[62] D. F. Polit, C. T. Beck, and S. V. Owen, Focus on research methods: Is the CVI an acceptable indicator of content validity? Appraisal and recommendations, Res. Nursing Health 30, 459 (2007).

[63] D. V. Cicchetti and S. Sparrow, Developing criteria for establishing interrater reliability of specific items: Application to assessment of adaptive behavior, American Journal of Mental Deficiency 86, 127 (1981).

[64] J. Fleiss, Statistical Methods for Rates and Proportions, 2nd ed. (John Wiley, New York, 1981).

[65] H. I. Akbulut, Examining the effect of instruction with dual situated learning model on students' cognitive achievement and conceptual change: Force and motion unit sample, Ph.D. thesis, Karadeniz Technical University, Trabzon, 2013. [(to be published) in Turkish].

[66] C. T. Chia, Common misconceptions in frictional force among university physics students, Teach. Learn. 16, 107 (1996).

[67] L. G. Rimoldini and C. Singh, Student understanding of rotational and rolling motion concepts, Phys. Rev. ST Phys. Educ. Res. 1, 010102 (2005).

[68] A. Hapkiewicz, Finding a list of science misconceptions, MSTA Newsletter 38 (Winter), 11-14 (1992).

[69] E. Tavukçuoğlu, Investigating high school students' cognitive structures about friction, acceleration and inertia concepts, Master's thesis, Hacettepe University, Ankara, 2018. [(unpublished) in Turkish].

[70] B. A. Sherwood and W. H. Bernard, Work and heat transfer in the presence of sliding friction, Am. J. Phys. 52, 1001 (1984).

[71] A. De Ambrosis, M. Malgieri, P. Mascheretti, and P. Onorato, Investigating the role of sliding friction in rolling motion: a teaching sequence based on experiments and simulations, Eur. J. Phys. 36, 035020 (2015).

[72] S. Prasitpong, R. Chitaree, and S. Rakkapao, Studying the frictional force directions via bristles, Phys. Educ. 45, 602 (2010).

[73] S. Alaci, F. C. Ciornei, I. C. Romanu, and M. C. Ciornei, Upon the relationship between rolling friction and sliding friction, IOP Conf. Series: Materials Sci. Engin. 400, 042002 (2018).

[74] T. Ecevit and P. Ö. Şimşek, The evaluation of teachers' science concept teaching and their action to diagnose and eliminate misconceptions, Elem. Educ. Online 16, 129 (2017).

[75] S. Soeharto, B. Csapó, E. Sarimanah, F. I. Dewi, and T. Sabri, A review of students' common misconceptions in 
science and their diagnostic assessment tools, J. Pendidikan IPA Indonesia 8, 247 (2019).

[76] S. Yavuz, A content analysis related to theses about misconceptions in chemistry education: The case of Turkey (2005-2015), Kastamonu Educ. J. 25, 957 (2017).

[77] H. Ş. Kızılcık and B. Güneş, Developing three-tire misconception test about regular circular motion, Hacettepe University J. Educ. 41, 278 (2011).

[78] N. Önder-Çelikkanlı, Development of four-tier misconception test on electrification, Ph.D. thesis, Gazi University, Ankara, 2019 (to be published).

[79] I. A. Halloun and D. Hestenes, The initial knowledge state of college physics students, Am. J. Phys. 53, 1043 (1985).

[80] D. Kaltakci-Gurel, A. Eryilmaz, and L. C. McDermott, Development and application of a four-tier test to assess pre-service physics teachers' misconceptions about geometrical optics, Res. Sci. Technol. Educ. 35, 238 (2017).

[81] J. Krim, Surface science and the atomic-scale origins of friction: What once was old is new again, Surf. Sci. 500, 741 (2002).
[82] U. Besson, L. Borghi, A. De Ambrosis, and P. Mascheretti, How to teach friction: Experiments and models, Am. J. Phys. 75, 1106 (2007).

[83] D. Hestenes, M. Wells, and G. Swackhamer, Force Concept Inventory, Phys. Teach. 30, 141 (1992).

[84] R. K. Thornton and D. R. Sokoloff, Assessing student learning of Newton's Laws: The Force and Motion Conceptual Evaluation and the evaluation of active learning laboratory and lecture curricula, Am. J. Phys. 66, 338 (1998).

[85] D. Hestenes and M. Wells, A mechanics baseline test, Phys. Teach. 30, 159 (1992).

[86] H. P. Chang, J. Y. Chen, C. J. Guo, C. C. Chen, C. Y. Chang, S. Y. Lin, W. J. Su, K. D. Lain, S. Y. Hsu, J. L. Lin, C. C. Chen, Y. T. Cheng, L. S. Wang, and Y. T. Tseng, Investigating primary and secondary students' learning of physics concepts in Taiwan, Int. J. Sci. Educ. 29, 465 (2007).

[87] E. Şahin, M. Aygün, N. Önder-Çelikkanlı, H. Ş. Kızılcık, T. Taşkın, V. Damlı, O. Türk, G. Önsal, and B. Güneş, Misconceptions about frictional force between solid surfaces, oral presentation, in Proceedings of the Turkish Physical Society 32nd International Physics Congress, Bodrum-Turkey (Turkish Physical Society, Istanbul, 2016). 